\title{
Article \\ Boosting Polyamines to Enhance Shoot Regeneration in Potato (Solanum tuberosum L.) Using $\mathrm{AgNO}_{3}$
}

\author{
Walaa M. R. M. Adly ${ }^{1}$, Yasser S. A. Mazrou ${ }^{2,3}{ }^{\mathbb{D}}$, Mohammad E. EL-Denary ${ }^{1, *}$, Mahasen A. Mohamed ${ }^{1}$, \\ El-Sayed T. Abd El-Salam ${ }^{4}$ and Ahmed S. Fouad ${ }^{4}$ \\ 1 Horticulture Research Institute, Agriculture Research Center, Giza 12619, Egypt; \\ DR.Walaa.Adly@gmail.com (W.M.R.M.A.); dr.mahasen.hakem@gmail.com (M.A.M.) \\ 2 Business Administration Department, Community College, King Khalid University, Guraiger, \\ Abha 62529, Saudi Arabia \\ 3 Department of Agriculture Economic, Faculty of Agriculture, Tanta University, Tanta 31527, Egypt; \\ yasser.mazroua@agr.tanta.edu.eg \\ 4 Botany and Microbiology Department, Faculty of Science, Cairo University, Giza 12613, Egypt; \\ tsayed1969@hotmail.com (E.-S.T.A.E.-S.); ahmedsfouad@yahoo.com or ahmedsfouad@sci.cu.edu.eg (A.S.F.) \\ * Correspondence: dr.m.eldenary@gmail.com
}

check for updates

Citation: Adly, W.M.R.M.; Mazrou, Y.S.A.; EL-Denary, M.E.; Mohamed, M.A.; Abd El-Salam, E.-S.T.; Fouad, A.S. Boosting Polyamines to Enhance Shoot Regeneration in Potato (Solanum tuberosum L.) Using $\mathrm{AgNO}_{3}$. Horticulturae 2022, 8, 113.

https://doi.org/10.3390/

horticulturae 8020113

Academic Editor: Kin-Ying To

Received: 13 December 2021

Accepted: 17 January 2022

Published: 27 January 2022

Publisher's Note: MDPI stays neutral with regard to jurisdictional claims in published maps and institutional affiliations.

Copyright: (C) 2022 by the authors. Licensee MDPI, Basel, Switzerland. This article is an open access article distributed under the terms and conditions of the Creative Commons Attribution (CC BY) license (https:// creativecommons.org/licenses/by/ $4.0 /)$.

\begin{abstract}
Advancements in shoot regeneration systems support biotechnology-based tools used in the genetic improvement of plant crops. This study aims to enhance shoot regeneration in potatoes by boosting polyamine content by adding $\mathrm{AgNO}_{3}$ to the shoot regeneration medium (MS medium supplemented with $30 \mathrm{~g} \mathrm{~L}^{-1}$ sucrose, $100 \mathrm{mg} \mathrm{L}^{-1}$ myoinositol, and $2.25 \mathrm{BA} \mathrm{mg} \mathrm{L}^{-1}$ ). Five concentrations of $\mathrm{AgNO}_{3}\left(2,4,6,8\right.$, and $\left.10 \mathrm{mg} \mathrm{L}^{-1}\right)$ were used in addition to a control. The effect of $\mathrm{AgNO}_{3}$ on regeneration assumed a more or less concentration-dependent bell-shaped curve peaking at $4 \mathrm{mg} \mathrm{L}^{-1}$. Enhancements in shoot regeneration were attributed to the known role of $\mathrm{AgNO}_{3}$ as an ethylene action blocker in addition to improvements in polyamine accumulation without an increase in $\mathrm{H}_{2} \mathrm{O}_{2}$ content, lipid peroxidation, or DNA damage. The uncoupling of shoot regeneration and polyamine content recorded at high $\mathrm{AgNO}_{3}$ concentrations can be attributed to the consumption of polyamines to counteract the synchronized oxidative stress manifested by increases in $\mathrm{H}_{2} \mathrm{O}_{2}$ content, lipid peroxidation, and DNA damage.
\end{abstract}

Keywords: potato; polyamines; callus; shoot regeneration; $\mathrm{H}_{2} \mathrm{O}_{2}$; MDA; comet

\section{Introduction}

Potato (Solanum tuberosum) is the most important non-cereal food crop with annual world production of 370 million tons harvested from 17.34 million hectares (FAO 2019 https://www.fao.org/faostat/ar/\#data/QCL, accessed on 11 November 2021). Tubers are an essential origin for energy and protein. They also introduce essential nutrients to a diet, including vitamins $\left(\mathrm{B}_{1}, \mathrm{~B}_{3}, \mathrm{~B}_{6}\right.$ and $\mathrm{C}$ ), minerals (potassium, phosphorus, magnesium, zinc, and iron) in addition to folate, pantothenic acid, riboflavin, and dietary fiber [1]. Compared to other food crops, potatoes can produce more energy, proteins, minerals, and vitamins per unit of time and land area [2]. In addition to indoor uses, potatoes are used in many food industries [3] that generate a huge amount of peel used in bioethanol production [4].

Conventional potato breeding is a difficult task due to the tetraploid nature and high heterozygosity of the potato genomes. The first is responsible for inbreeding depression and intra-species incompatibilities, while the second prevents the incorporation of new traits through conventional breeding [5]. In addition, searching for functional genetic variability in wild relatives is laborious and time-consuming [6,7].

Biotechnology can hasten potato breeding through in vitro selection [8] and transformation [9]. However, biotechnological tools require establishing a regeneration system to obtain genetically improved lines [10]. Thus, studying factors affecting regeneration in 
potatoes adds to the genetic improvement of this vital crop. Generally, shoot regeneration depends on genotype, type of the explant used, the hormonal combination used in the regeneration medium, and growth conditions [11].

Different explant types were examined for their potential use in direct and indirect shoot regeneration, including tuber discs, intermodal segments, petioles, leaves, meristems, and anthers [12,13]. However, the leaf and internode are the most widely used explants.

Shoot regeneration always occurs on a medium containing the appropriate concentrations of auxins and cytokinins [14]. Most regeneration protocols for potatoes utilize a mixture of 6-benzylaminopurine (BA) and naphthalene acetic acid (NAA) that produces the highest percentage of shoot regeneration from leaf and internodal explants [13].

Polyamines are nitrogenous, aliphatic, water-soluble, low molecular weight polycationic compounds with at least three amino groups found in all living organisms [15]. They are essential for several physiological processes, including organogenesis, embryogenesis, fruit maturation, and senescence, in addition to responses to abiotic and biotic stresses [16]. However, the high cost of polyamines encourages trials to find less expensive alternatives.

Both ethylene and polyamines share the same precursor, S-adenosyl-L-methionine, for their synthesis $[17,18]$. In addition, ethylene inhibits methionine decarboxylase and arginine decarboxylase S-adenosyl activities necessary for polyamine synthesis $[19,20]$. Plant cells are sensitive to small, non-toxic concentrations of $\mathrm{Ag}^{+}$ions that have a profound effect on organogenesis and somatic embryogenesis. $\mathrm{Ag}^{+}$ions can mitigate the negative impact of ethylene accumulation on shoot regeneration by blocking the ethylene receptor through replacing the copper ion cofactor of the ethylene binding site [21]. Thus, $\mathrm{Ag}^{+}$ incorporation in culture medium may be a cost-reasonable strategy to enhance polyamine accumulation in plant tissues and thereby alter many developmental aspects [22-24]. It is widely used to enhance regeneration in many plant species including potato $[25,26]$.

Therefore, the aim of this study is to evaluate the impact of five different concentrations of $\mathrm{AgNO}_{3}\left(2,4,6,8\right.$, and $\left.10 \mathrm{mg} \mathrm{L}^{-1}\right)$ on shoot regeneration from internode-sourced callus as well as the growth of regenerated shoots in potato (Solanum tuberosum L.) in relation to polyamine accumulation.

\section{Materials and Methods}

\subsection{Explant Preparation}

Virus-free tubers of potato (Solanum tuberosum) were kindly provided from the Agricultural Research Center, Cairo, Egypt. Tubers were stored at $10{ }^{\circ} \mathrm{C}$ till sprouting, then sprouts were detached from tubers and submerged in tap water containing a few drops of a liquid detergent, shaken for $10 \mathrm{~min}$, then rinsed in running tap water for 30 min to remove the detergent. Washed sprouts were transferred to a $250 \mathrm{~mL}$ closed jar containing $100 \mathrm{~mL}$ of $20 \%$ commercial Clorox and a few drops of Tween 20, then shaken for five minutes. The solution was decanted, and sprouts were washed thoroughly with sterile distilled water in a laminar flow cabinet.

Meristems were excised aseptically under binuclear microscope and placed in sterilized tubes (one shoot tip/tube), each containing $10 \mathrm{~mL}$ sterilized basal medium (MS medium [27] supplemented with $30 \mathrm{~g} \mathrm{~L}^{-1}$ sucrose and $100 \mathrm{mg} \mathrm{L}^{-1}$ myoinositol) to which $2 \mathrm{mg} \mathrm{L}^{-1}$ calcium pantothenate, $0.1 \mathrm{mg} \mathrm{L}^{-1}$ gibberellic acid $\left(\mathrm{GA}_{3}\right)$, and $0.01 \mathrm{mg} \mathrm{L}^{-1} \mathrm{NAA}$ were added. The $\mathrm{pH}$ was adjusted to 5.7 ; the medium was solidified using $7 \mathrm{~g} \mathrm{~L}^{-1}$ agar and autoclaved at $121^{\circ} \mathrm{C}$ for $20 \mathrm{~min}$. Cultures were maintained at $25^{\circ} \mathrm{C}$ under a $16 / 8 \mathrm{~h}$ light/dark cycle (light intensity 2000 lux). The same growth conditions were applied throughout the study. Six weeks later, shoots about $5-7 \mathrm{~cm}$ long were obtained and micropropagated by nodal cuttings with a subculture step repeated every 3 weeks. Micropropagation was carried out in $400 \mathrm{~mL}$ glass jars (6 cuttings/jar), each containing about $50 \mathrm{~mL}$ basal medium under the same growth conditions. The resulting plants were a source for internode explants for callus initiation. 


\subsection{Callus Induction and Plant Regeneration}

Based on preliminary experiments, an approximately $1 \mathrm{~cm}$ segment was excised from the middle internode of each donor plant and inoculated on callus induction medium in $9 \mathrm{~cm}$ Petri dishes (10 explants/dish). The medium consisted of basal medium supplemented with $0.186 \mathrm{mg} \mathrm{L}^{-1} \mathrm{NAA}$ and $2.25 \mathrm{mg} \mathrm{L}^{-1}$ BA. Explants were transferred every two weeks to the same medium, but fresh. After six weeks, callus induction \% was calculated, and explants along with their resultant calli were transferred to regeneration media. Five regeneration media of basal medium fortified with $2.25 \mathrm{mg} \mathrm{L}^{-1} \mathrm{BA}$ and filter sterilized $\mathrm{AgNO}_{3}$ at $0,2,4,6,8$, and $10 \mathrm{mg} \mathrm{L}^{-1}$ were employed. Cultures were transferred biweekly onto the same medium, but fresh.

After six weeks, shoot regeneration \%, average number of shoots per explant, and the average fresh weights of the regenerated shoots were determined. Samples from each treatment were directed to polyamines, hydrogen peroxide $\left(\mathrm{H}_{2} \mathrm{O}_{2}\right)$, malondialdehyde (MDA), and chlorophyll determinations, as well as a comet assay.

\subsection{Quantification of Total Chlorophyll}

Leaf tissues (20 mg) were ground in $2 \mathrm{~mL}$ pre-chilled acetone $80 \%(v / v)$ according to Merwad et al. [28]. The optical density of the clear extract was read at 662 and $644 \mathrm{~nm}$ against acetone, and chlorophyll content was determined $\mathrm{nm}$ using MacKinney equations [29]:

$$
\text { Chlorophyll content }\left(\mu \mathrm{g} \mathrm{mL}^{-1}\right)=5.13 \mathrm{E}_{662}+20.41 \mathrm{E}_{644}
$$

\subsection{Polyamine Determinations}

Polyamines were extracted by homogenizing $200 \mathrm{mg}$ liquid nitrogen-powdered tissues in $1 \mathrm{~mL}$ of $5 \%$ perchloric acid for one hour, then centrifuged at $15,000 \times g$ at $4{ }^{\circ} \mathrm{C}$ for $15 \mathrm{~min}$ [30]. The supernatant was neutralized using $5 \mathrm{~N} \mathrm{KOH}$ and stored at $-20^{\circ} \mathrm{C}$ till use. Polyamines were colorimetrically quantified in the regenerated shoots, according to Federico et al. [31]. One mL reaction mixture containing $400 \mathrm{mM}$ Na-phosphate buffer, $\mathrm{pH} 6.8,0.1$ unit of amine oxidase (Ray Biotech), and $20 \mu \mathrm{L}$ of the sample was incubated at $37^{\circ} \mathrm{C}$. After $10 \mathrm{~min}$ the reaction was stopped using $200 \mu \mathrm{L}$ of $10 \%$ trichloroacetic acid (TCA), thereafter the suspension was centrifuged at $15,000 \times g$ for $15 \mathrm{~min}$. The supernatant was mixed with ninhydrin reagent $(2.5 \mathrm{~g}$ ninhydrin and $376 \mathrm{mg}$ hydrindantin in $60 \mathrm{~mL}$ glacial acetic acid and $40 \mathrm{~mL} 6 \mathrm{M}$ o-phosphoric acid) and glacial acetic acid and incubated in boiling water bath for $30 \mathrm{~min}$ then cooled and OD was measured at $510 \mathrm{~nm}$. The polyamine content was determined based on the spermidine standard curve.

\section{5. $\mathrm{H}_{2} \mathrm{O}_{2}$ Determination}

$\mathrm{H}_{2} \mathrm{O}_{2}$ content was quantified following the method described by Loreto and Velikova [32]. A number of $0.2 \mathrm{~g}$ liquid nitrogen-powdered tissues were homogenized in $2.5 \mathrm{~mL}$ of $0.1 \%(w / v)$ TCA in an ice bath. After centrifugation for $20 \mathrm{~min}$ at $4{ }^{\circ} \mathrm{C}$ and $15,000 \times g, 0.5 \mathrm{~mL}$ of the clear supernatant was mixed with an equal volume of $10 \mathrm{mM}$ potassium phosphate buffer $(\mathrm{pH} 7.0)$ and a double volume of $1.0 \mathrm{M} \mathrm{KI}$. The absorbance was observed at $390 \mathrm{~nm}$, and the amount of $\mathrm{H}_{2} \mathrm{O}_{2}\left(\mathrm{nM} \mathrm{g}^{-1}\right.$ fresh weight) was calculated based on a standard curve constructed using different known concentrations of $\mathrm{H}_{2} \mathrm{O}_{2}$.

\subsection{Lipid Peroxidation}

Lipid peroxidation was measured by the quantification of MDA formation following Stewart and Bewley [33]. Samples of regenerated shoots of all treatments were homogenized in Tris- $\mathrm{HCl}$ buffer (100 mM, pH 7.4) containing PVP (1.5\%). The homogenates were filtered, and then the filtrates were centrifuged for $15 \mathrm{~min}$ at $12,000 \times \mathrm{g}$. The supernatant was mixed with $4 \mathrm{~mL} 2$-thiobarbituric acid $(0.5 \%)$ dissolved in $20 \%$ trichloroacetic acid in a $1: 4$ ratio and kept at $90^{\circ} \mathrm{C}$ for $30 \mathrm{~min}$ and then cooled rapidly. The cooled samples were centrifuged at $10,000 \times g$ for $20 \mathrm{~min}$ and the OD of the supernatants was recorded at $532 \mathrm{~nm}$. 
After subtraction of the nonspecific absorbance at $600 \mathrm{~nm}$, MDA content was calculated as $\mathrm{nM} \mathrm{g}^{-1}$ fresh weight using its extinction coefficient $\left(155 \mathrm{mM}^{-1} \mathrm{~cm}^{-1}\right)$.

\subsection{Comet Assay}

DNA damage was estimated in regenerated shoots using an alkaline comet assay outlined by Tice et al. [34] with some modifications. Tissues were homogenized in a cold mincing solution to release the nuclei. The mincing solution consists of Hanks' Balanced Salt Solution (HBSS), lacking calcium and magnesium cations and supplemented with $20 \mathrm{mM}$ EDTA and 10\% dimethylsulphoxide (DMSO). A $10 \mu \mathrm{L}$ aliquot of cell suspension containing approximately 10,000 cells was blended with $75 \mu \mathrm{L}(0.5 \%)$ low melting point agarose and spread on an ice-cooled glass slide pre-immersed in $1 \%$ normal melting agarose. Thereafter, the solidified slides were kept in chilled lysis buffer (10 mM Tris, $\mathrm{pH} 10,2.5 \mathrm{M}$ $\mathrm{NaCl}$, and $100 \mathrm{mM}$ EDTA) freshly supplemented with $1 \%$ Triton X-100 and 10\% DMSO at $4{ }^{\circ} \mathrm{C}$ in darkness. After $24 \mathrm{~h}$, the slides were kept for $20 \mathrm{~min}$ in fresh alkaline buffer ( $\mathrm{pH} \mathrm{13}$ ): $300 \mathrm{mM} \mathrm{NaOH}$ and $1 \mathrm{mM}$ EDTA. The uncoiled DNA was electrophoresed for $20 \mathrm{~min}$ at $25 \mathrm{~V}(0.90 \mathrm{~V} / \mathrm{cm})$ and $300 \mathrm{~mA}$. The products were neutralized in $0.4 \mathrm{M}$ Trizma base and finally fixed in chilled absolute ethanol.

After air-drying at room temperature, the extent of DNA fragments' departure from the nucleoid was recorded by capturing and scoring images of 50 ethidium bromide-stained cells using Komet 5 image analysis software established by Kinetic Imaging, Ltd. (Liverpool, UK). The amplitude of DNA damage was evaluated by calculating \% tail DNA (tDNA). tDNA calculated in shoots regenerated on $\mathrm{AgNO}_{3}$-free medium was considered as the unit for DNA damage.

\subsection{Statistical Analysis}

Results of each treatment were represented as the mean of 3 replicates \pm standard deviation (SD). The least significant difference (LSD) between treatments was evaluated at $p \leq 0.05$ using Statistica software version 7 .

\section{Results}

\subsection{Callus Induction and Shoot Regeneration}

In vitro potato plants (Figure 1) were used as a source for the internode explants. On the callus induction medium, the explants swelled, and nodular green calli started to appear at the cut margins of all internode explants after 2 weeks (Figure 2). Following transfer to shoot regeneration media, calli extended to cover the whole surface of explant, and regenerated shoots started to appear at the third week on all regeneration media (Figure 3).

In the absence of $\mathrm{AgNO}_{3}$, about $37 \%$ of calli produced shoots on the regeneration medium (Figure 4a). Shoot regeneration \% increased gradually following the increase in $\mathrm{AgNO}_{3}$ concentration, reaching about 1.33 folds of control at $4 \mathrm{mg} \mathrm{L}^{-1}$. The stimulatory effect of $\mathrm{AgNO}_{3}$ decreased at $6 \mathrm{mg} \mathrm{L}^{-1}$, disappeared at $8 \mathrm{mg} \mathrm{L}^{-1}$, and finally reversed at $10 \mathrm{mg} \mathrm{L}^{-1}$, where shoot regeneration \% reached about $75 \%$ of control. The average number of shoots per explant increased gradually with an increase in $\mathrm{AgNO}_{3}$ concentration reaching about 2.3 folds of control at $4 \mathrm{mg} \mathrm{L}^{-1}$, then fell to 1.6 folds of control at $6 \mathrm{mg} \mathrm{L}^{-1}$ (Figures 3 and $4 \mathrm{~b}$ ). Exceeding $6 \mathrm{mg} \mathrm{L}^{-1}$, the number of shoots dropped below the control level reaching about $46 \%$ of control at $10 \mathrm{mg} \mathrm{L}^{-1}$. 


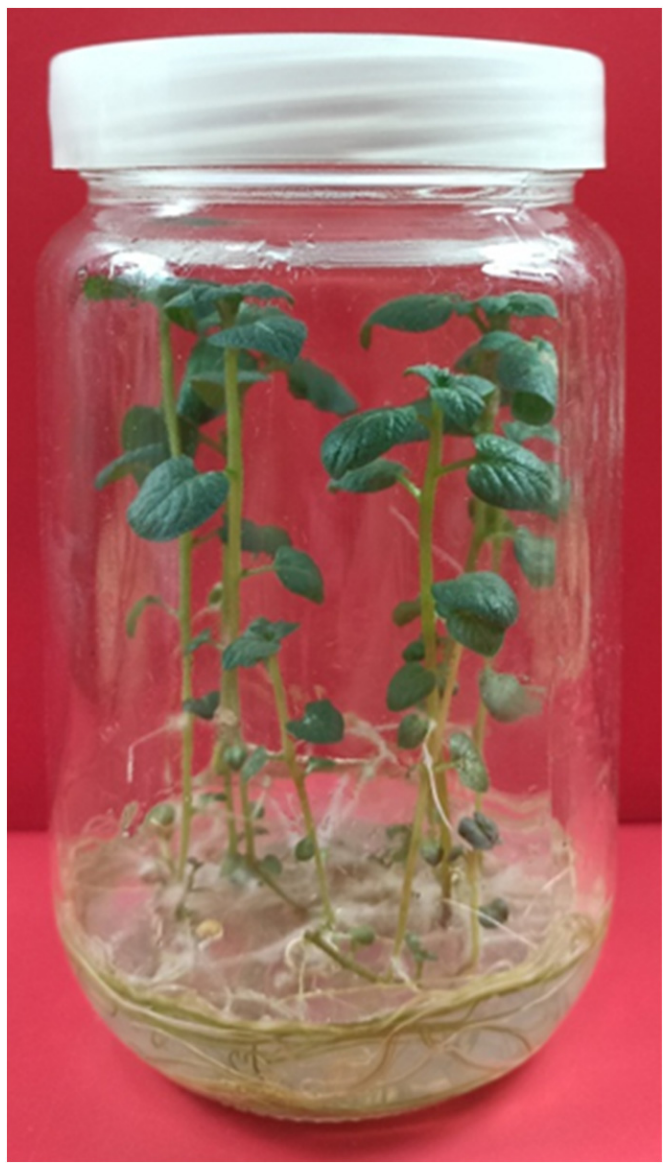

Figure 1. Four week old potato in vitro plants propagated by nodal cuttings, grown on basal medium and maintained at $25^{\circ} \mathrm{C}$ under $16 / 8 \mathrm{~h}$ light/dark cycle (light intensity $2000 \mathrm{lux}$ ).

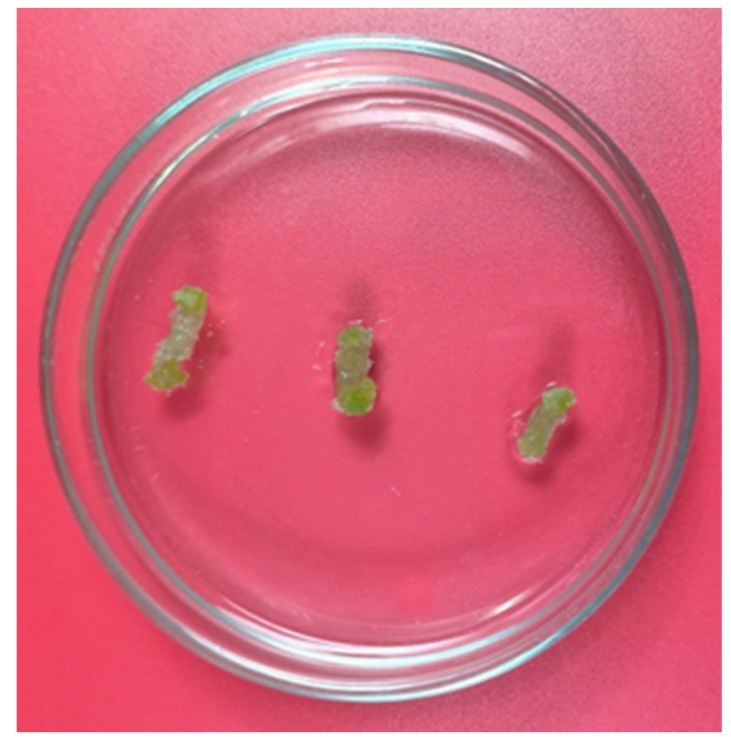

Figure 2. Six week old calli induced on internode explants grown on basal medium supplemented

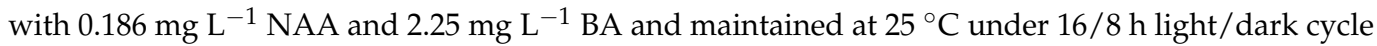
(light intensity 2000 lux). 


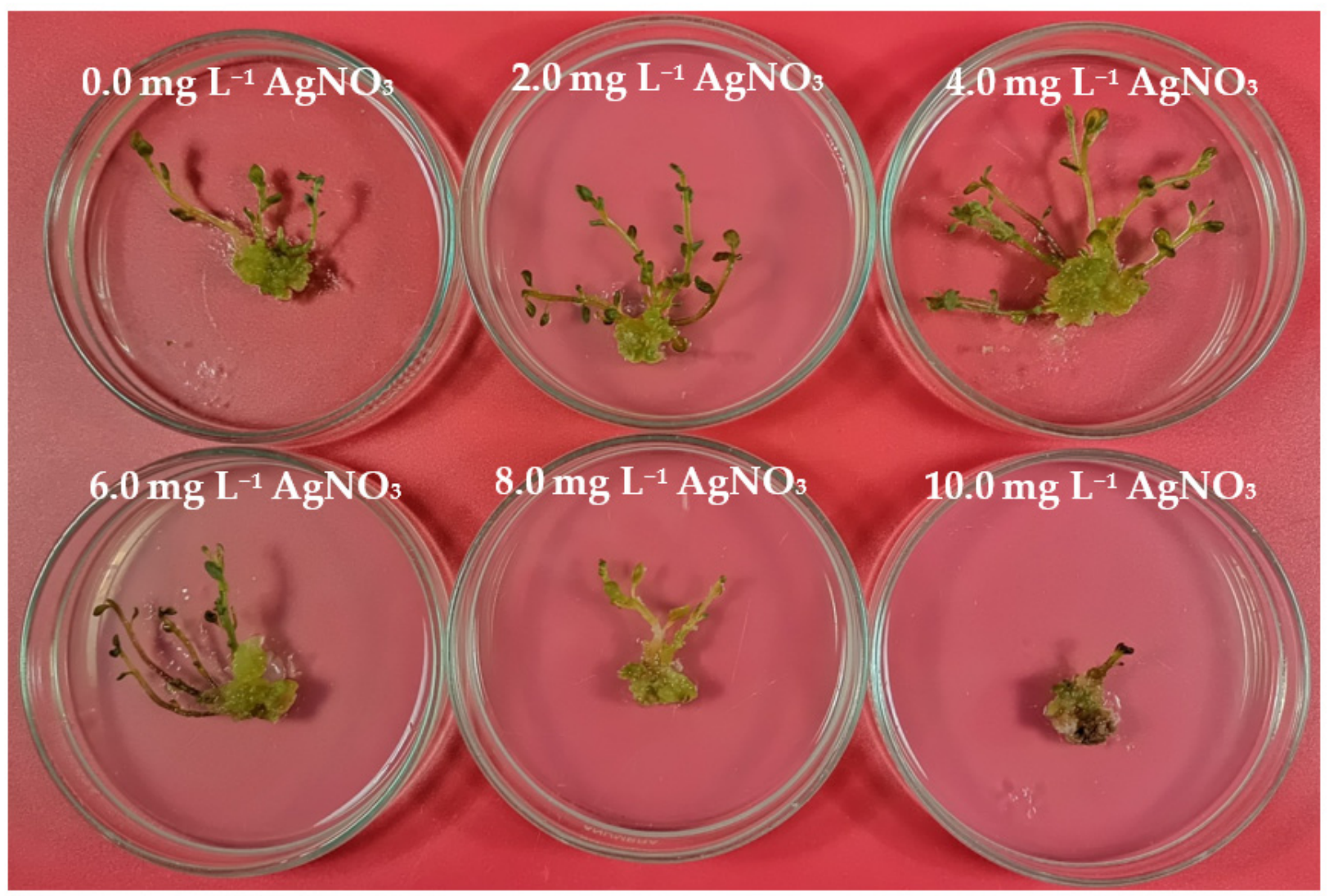

Figure 3. Six week old shoots regenerated from calli grown on basal medium supplemented with $2.25 \mathrm{mg} \mathrm{L}^{-1} \mathrm{BA}$ and different concentrations of $\mathrm{AgNO}_{3}$ and maintained at $25{ }^{\circ} \mathrm{C}$ under $16 / 8 \mathrm{~h}$ light/dark cycle (light intensity 2000 lux).

$\mathrm{AgNO}_{3}$ gradually improved the average fresh weight of regenerated shoots, reaching about 1.5 folds of control at $4 \mathrm{mg} \mathrm{L}^{-1}$ (Figure $4 \mathrm{c}$ ). Further increases in $\mathrm{AgNO}_{3}$ concentration were accompanied by a gradual decrease in fresh weight to reach about $65 \%$ of control at $10 \mathrm{mg} \mathrm{L}^{-1}$, remaining significantly higher than control at $6 \mathrm{mg} \mathrm{L}^{-1}$. The same behavior was reflected by the chlorophyll content of the regenerated shoot in response to an increasing $\mathrm{AgNO}_{3}$ concentration, except for the absence of significant change at $6 \mathrm{mg} \mathrm{L}^{-1}$ (Figure $4 \mathrm{~d}$ ).

\subsection{Polyamine Content}

In the absence of $\mathrm{AgNO}_{3}$, polyamine determination reflected about $450 \mu \mathrm{g}$ in each gram of regenerated shoots on a fresh weight basis (Figure 5). Polyamine accumulation increased in response to introducing $\mathrm{AgNO}_{3}$ into the regeneration medium, in a concentrationdependent manner, reaching about 3.6 folds of control at $8 \mathrm{mg} \mathrm{L}^{-1}$ that remained insignificantly changed with further increases in $\mathrm{AgNO}_{3}$ concentration to $10 \mathrm{mg} \mathrm{L}^{-1}$. 


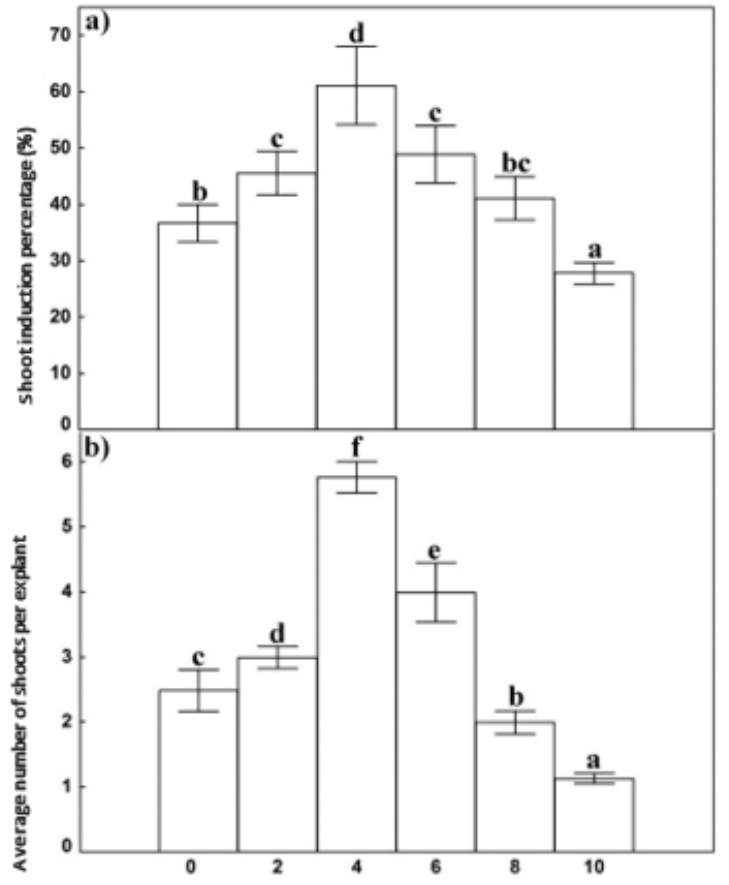

$\mathrm{AgNO}_{3}$ Concentration $\left(\mathrm{mg} \mathrm{L}^{-1}\right)$

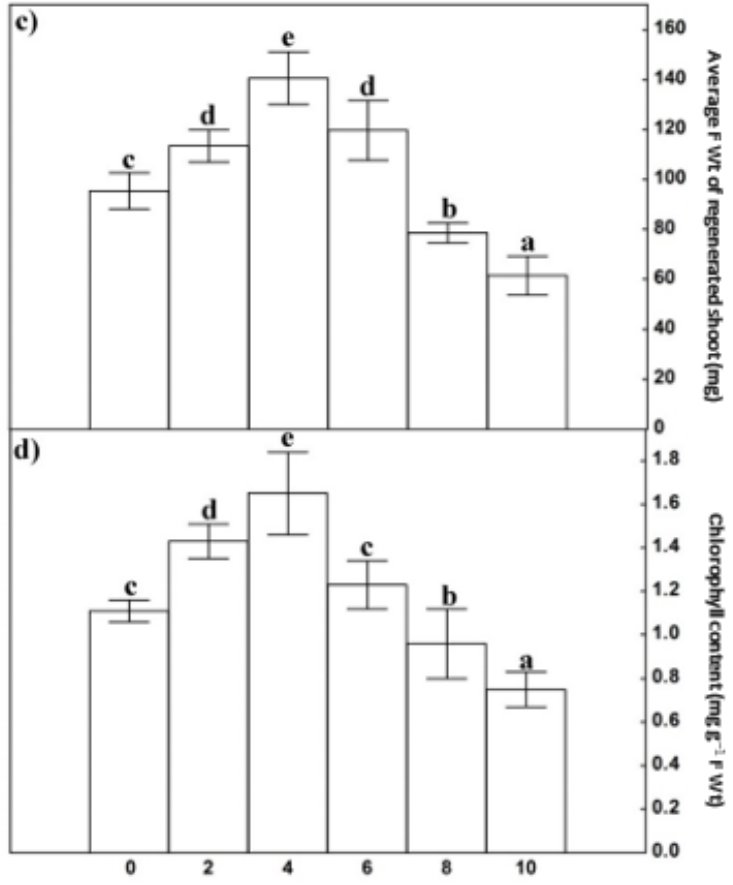

$\mathrm{AgNO}_{3}$ Concentration $\left(\mathrm{mg} \mathrm{L}^{-1}\right)$

Figure 4. Effect of AgNO3 at concentrations of 2, 4, 6, 8, and $10 \mathrm{mg} \mathrm{L}^{-1}$ on $\%$ of shoot regeneration (a), average number of regenerated shoots per explant (b), average weight of regenerated shoot (c), and chlorophyll content of regenerated shoots (d) of potato (Solanum tuberosum L.). Values are represented as mean \pm SD of triplicates; bars with different letters are significantly different, according to the LSD test, at $p<0.05$.

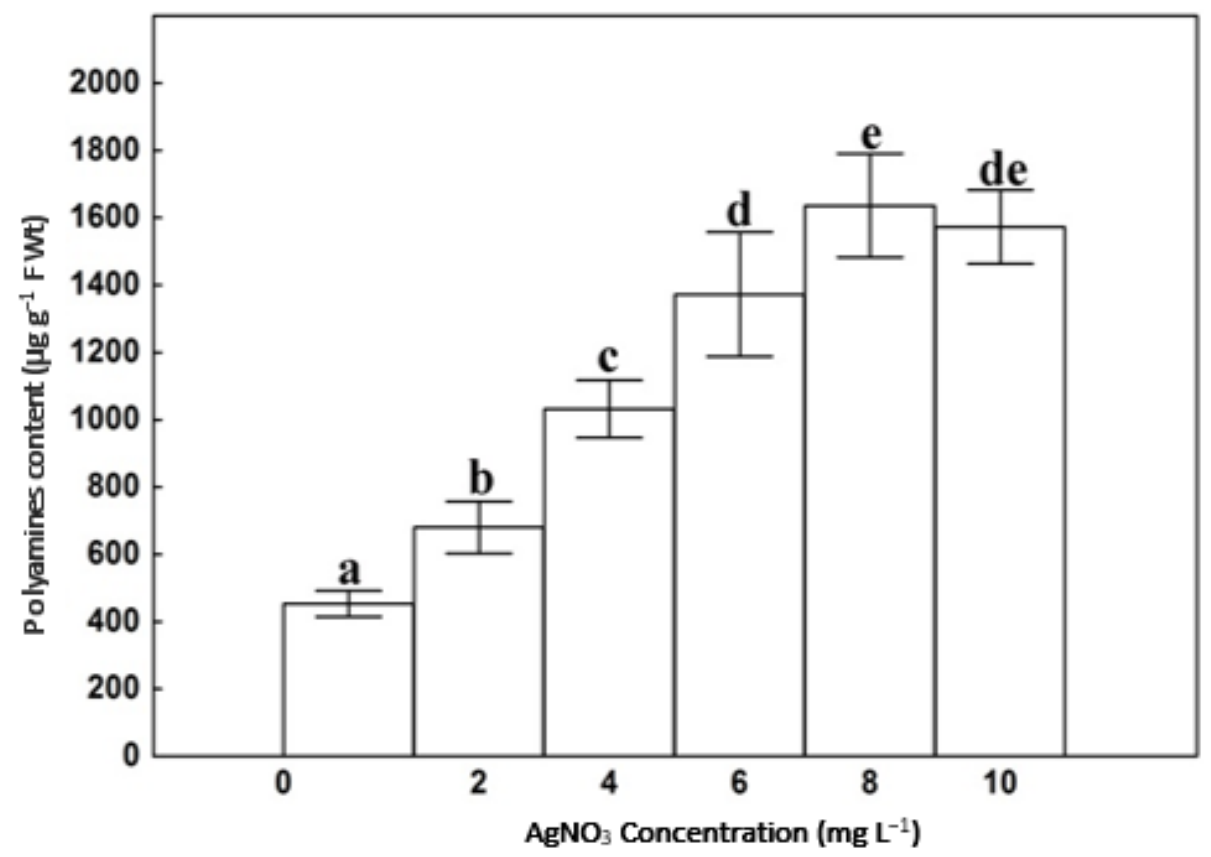

Figure 5. Effect of $\mathrm{AgNO}_{3}$ at concentrations of 2, 4, 6, 8, and $10 \mathrm{mg} \mathrm{L}^{-1}$ on polyamine content in regenerated shoots of potato (Solanum tuberosum L.). Values are represented as mean $\pm \mathrm{SD}$ of triplicates; bars with different letters are significantly different, according to the LSD test, at $p<0.05$. 


\section{3. $\mathrm{H}_{2} \mathrm{O}_{2}$ and $M D A$}

Compared with control, $\mathrm{H}_{2} \mathrm{O}_{2}$ content in regenerated shoots remained unaffected on media containing $\mathrm{AgNO}_{3}$ up to $6 \mathrm{mg} \mathrm{L}^{-1}$ (Figure 6a). Further increases in $\mathrm{AgNO}_{3}$ concentration were associated with a gradual increase in $\mathrm{H}_{2} \mathrm{O}_{2}$ content, reaching about 1.65 folds at $10 \mathrm{mg} \mathrm{L}^{-1}$. Similarly, lipid peroxidation, indicated with MDA formation, remained comparable with control up to $6 \mathrm{mg} \mathrm{L}^{-1}$ (Figure 6b). However, MDA content reached about 1.4 folds of control at $8 \mathrm{mg} \mathrm{L}^{-1}$ and remained without significant change following an increase in $\mathrm{AgNO}_{3}$ concentration.

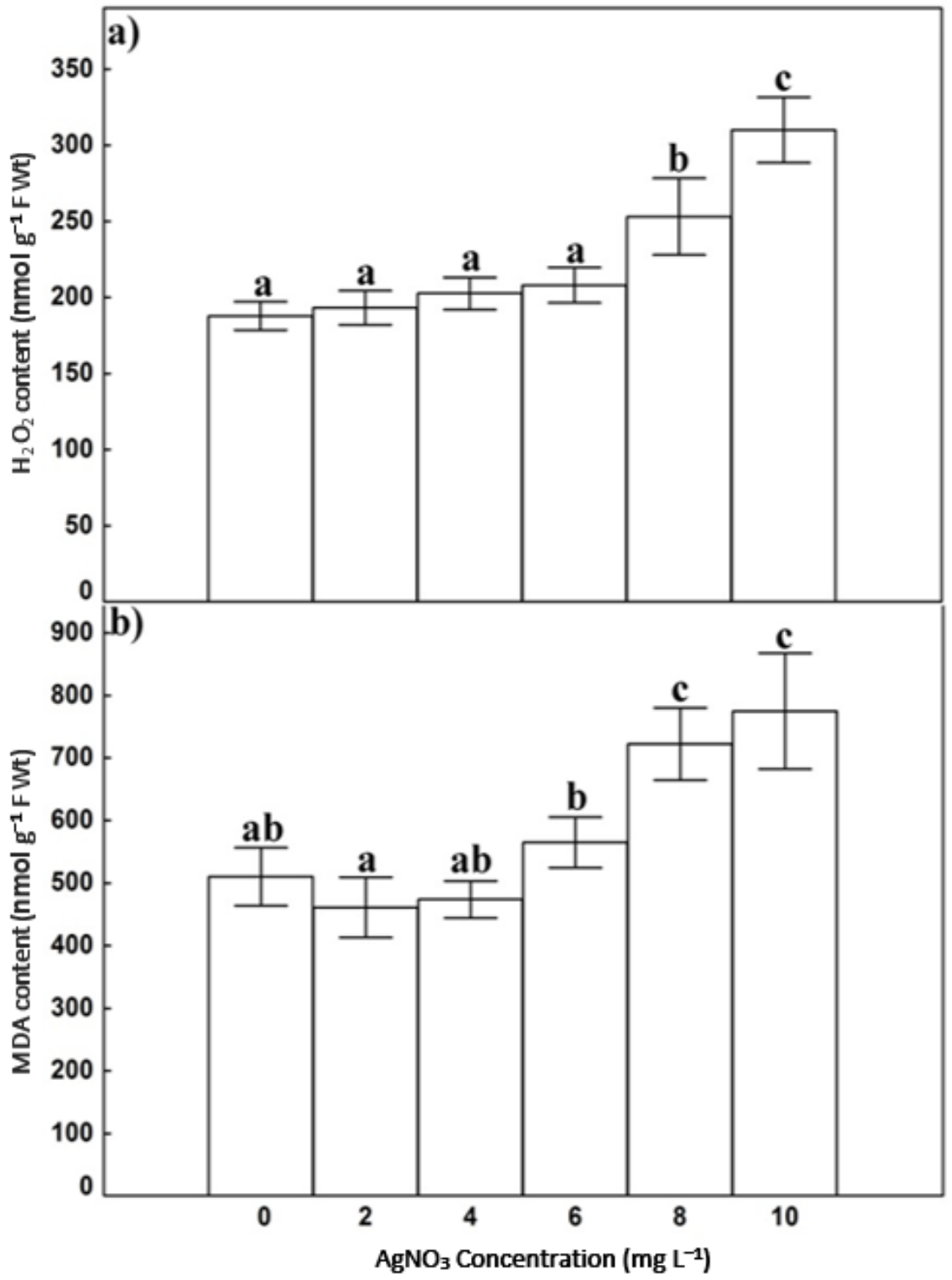

Figure 6. Effect of $\mathrm{AgNO}_{3}$ at concentrations of 2, 4, 6, 8, and $10 \mathrm{mg} \mathrm{L}^{-1}$ on $\mathrm{H}_{2} \mathrm{O}_{2}$ content (a) and MDA content (b) in regenerated shoots of potato (Solanum tuberosum L.). Values are represented as mean \pm SD of triplicates; bars with different letters are significantly different, according to the LSD test, at $p<0.05$.

\subsection{DNA Damage}

Estimation of DNA damage in regenerated shoots, represented as tDNA in comet assay, showed no harmful effect related to the utilization of 2-6 mg L${ }^{-1} \mathrm{AgNO}_{3}$ on genetic material (Figure 7). The application of higher concentrations of $\mathrm{AgNO}_{3}$ was associated with 
a gradual increase in DNA damage as indicated with the doubling of tDNA at $10 \mathrm{mg} \mathrm{L}^{-1}$, compared with control.

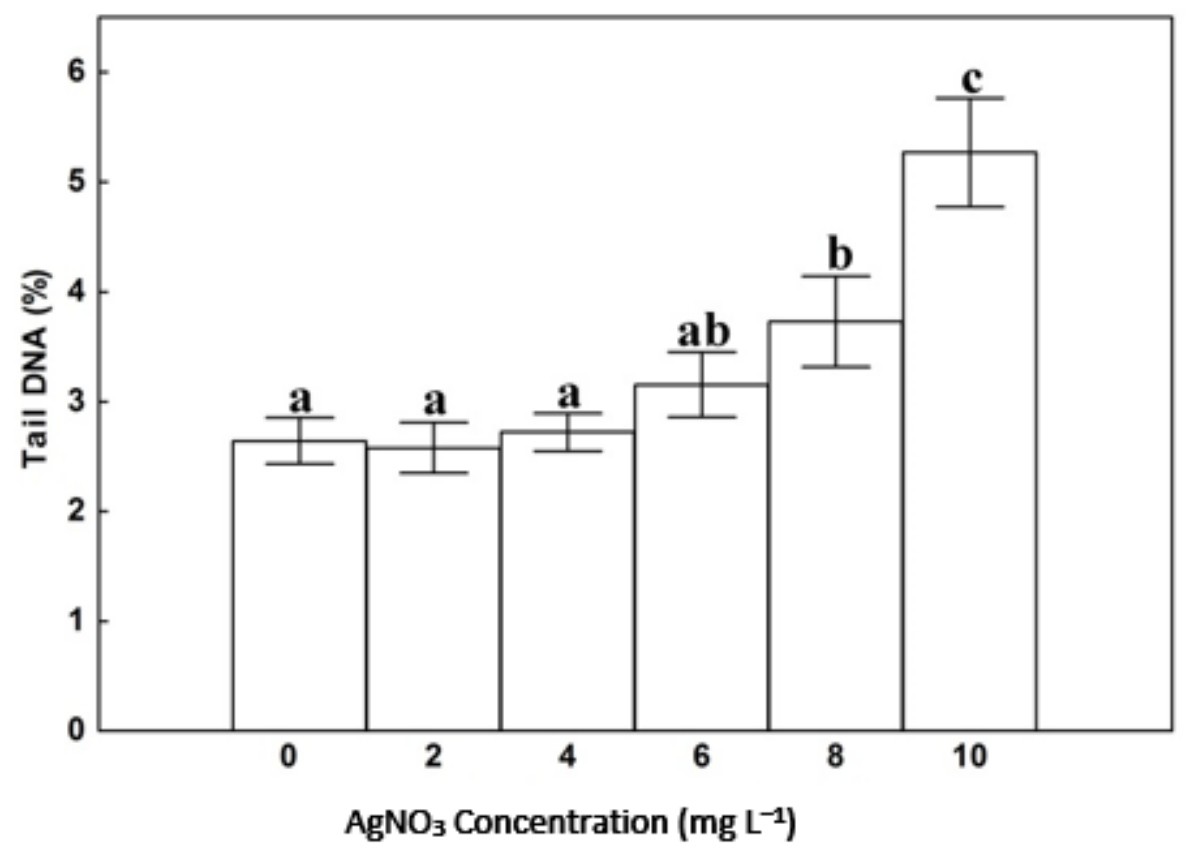

Figure 7. Effect of $\mathrm{AgNO}_{3}$ at concentrations of 2, 4, 6, 8, and $10 \mathrm{mg} \mathrm{L}^{-1}$ on tail DNA in regenerated shoots of potato (Solanum tuberosum L.). Values are represented as mean \pm SD of triplicates; bars with different letters are significantly different, according to the LSD test, at $p<0.05$.

\section{Discussion}

In the present work, callus induction was induced on all explants on medium containing $0.186 \mathrm{mg} \mathrm{L}^{-1} \mathrm{NAA}$ and $2.25 \mathrm{mg} \mathrm{L}^{-1} \mathrm{BA}$ and shoot regeneration was carried out following auxin elimination. Similarly, Kumlay, and Ercisli [13] used medium containing both auxin and cytokinin to initiate callus on internodes and leaf explants of four potato cultivars while shoot regeneration started following auxin withdrawal. The same strategy was applied by Ghosh et al. [35] starting with leaf explants of three potato cultivars. Auxins play an important role in the callus induction; they are believed to be related to a change in cell fate during which some somatic cells acquire pluripotency [36]. However, auxins provide limited flexibility of cell fate transition [37] that necessitates their elimination or at least decreasing their concentration in regeneration media. On the other hand, cytokinins affected callus induction through decreasing the cell wall lignification, facilitating callus initiation and in vitro growth [13]. They are the major players in regeneration media, where the shoot regeneration process is the result of interconnections among cytokinin receptors, cell cycles, and the development of shoot meristem [38].

Results of the current investigation emphasize the positive impact of small concentrations of $\mathrm{AgNO}_{3}$ on shoot regeneration and the growth of regenerated shoots. The response of the related parameters to $\mathrm{AgNO}_{3}$ concentration assumed a more or less concentrationdependent bell-shaped curve peaked at $4 \mathrm{mg} \mathrm{L}^{-1}$. With a genotype-dependent peak, the same trend was recorded for shoot regeneration in response to the increasing concentrations of $\mathrm{AgNO}_{3}$ in the potato cultivar 'Kufri Chipsona 1' [25,26,39], tomato [40], primrose [41], oat [42], and wheat [43]. It was also observed dealing with shoot growth and chlorophyll content in potato [26] and robusta coffee [44]. The dependence of the optimum concentration of the genotype may reflect a different tolerance to $\mathrm{Ag}^{+}$ion toxicity. In a related context, Kaur et al. [45] recorded the dependence of direct somatic embryogenesis in potato on the presence of $\mathrm{AgNO}_{3}$ in a culture medium. Moreover, the positive effect of $\mathrm{AgNO}_{3}$ on in vitro growth of potato shoots was recorded by Turhan [46]. 
The $\mathrm{AgNO}_{3}$-related improvements in shoot regeneration, recorded at low concentrations, can be explained by interference with ethylene perception that ameliorates the inhibitory impact of the accumulation of the gas hormone on shoot regeneration [21,43] and shoot growth [47]. The current results reflected only 33\% improvement in shoot regeneration $\%$ at $4 \mathrm{mg} \mathrm{L}^{-1}$, while the average number of regenerated shoots per explant reached 2.5 folds of control. Similar results were recorded in potato by Kaur and $\mathrm{Ku}-$ mar [39] reflecting the advantageous role of $\mathrm{AgNO}_{3}$ in the enhancement of the number of regenerated shoots per explant rather than the percentage of explants carrying regenerated shoots. These observations may highlight the unequal competence of explants for shoot regeneration and the appearance of the role of $\mathrm{AgNO}_{3}$ with competent explants only.

Our results afford another advantageous role for the addition of $\mathrm{AgNO}_{3}$ to the regeneration medium where improvements in shoot regeneration were associated with significant increases in polyamine content. The role of polyamines in the enhancement of morphogenesis and growth was documented early in potato shoot cultures [48]. A similar role for polyamines concerning shoot regeneration was documented in Picea abies [49], Cedrela fissilis [50], and Capparis decidua [51]. In addition, the role of polyamines in the enhancement of growth and chlorophyll content was also observed in Bakraii citrus [52] and Rosa hybrida [53].

Both ethylene and polyamines share the same precursor, S-adenosyl-L-methionine, for their synthesis $[17,18]$. In addition, ethylene inhibits methionine decarboxylase and arginine decarboxylase S-adenosyl activities necessary for polyamine synthesis in pea seedlings $[19,20]$. Thus, the promotive effect of ethylene inhibitors, e.g., $\mathrm{AgNO}_{3}$, on organogenesis was attributed to enhancements in polyamine biosynthesis rather than a reduction in ethylene production [22]. Interestingly, Kim et al. [54] reported improvements in the shoot regeneration in Polygonum tinctorium in response to introducing $\mathrm{AgNO}_{3}$ and the polyamine putrescine to the regeneration medium.

The negative impact of introducing $\mathrm{AgNO}_{3}$ to a regeneration medium starts at $8 \mathrm{mg} \mathrm{L}^{-1}$, where the average number of shoots per explant, the average weight of regenerated shoot, and the chlorophyll content decreased significantly without a significant decrease in the percentage of regeneration, reflecting that high concentrations impair shoot regeneration qualitatively then quantitatively. Both kinds of negative impacts of $\mathrm{AgNO}_{3}$ at high concentrations can be attributed to the accompanying significant increases in $\mathrm{H}_{2} \mathrm{O}_{2}$ content and the subsequent lipid peroxidation indicated by an increase in MDA content as well as the increase in DNA damage expressed as $\mathrm{tDNA} \%$. The $\mathrm{AgNO}_{3}$-induced oxidative stress manifested in our study by an increase in $\mathrm{H}_{2} \mathrm{O}_{2}$ content coupled with an increase in MDA content was also documented in Cucumis sativus [55] and tomato [56]. Heavymetal-induced oxidative stress accompanied by elevated levels of $\mathrm{H}_{2} \mathrm{O}_{2}$ and MDA was also recorded in potato shoot cultures exposed to cadmium [8].

$\mathrm{H}_{2} \mathrm{O}_{2}$ and other ROS generated during oxidative stress is associated with damage to cellular macromolecules, including DNA $[57,58]$ and chlorophyll $[59,60]$. The injurious impact of $\mathrm{H}_{2} \mathrm{O}_{2}$ on DNA supports its utilization as a positive control in plant comet assays [61]. In a similar context, Szpunar-Krok et al. [62] documented the hazardous effect on chlorophyll content of spaying potato plants with $\mathrm{H}_{2} \mathrm{O}_{2}$. Similarly, the synchronized increase in both $\mathrm{H}_{2} \mathrm{O}_{2}$ content and DNA damage manifested by tDNA\% was documented in potato plants experiencing salinity stress [63]. Additionally, Vishwakarma et al. [64] recorded the deterioration of DNA and photosynthetic pigments associated with growth retardation in response to $\mathrm{AgNO}_{3}$ at 1-3 mM in Brassica sp. The increase in polyamine content recorded at high $\mathrm{AgNO}_{3}$ concentrations synchronized with a decline in shoot regeneration reflects the depletion of polyamines in alleviating the ROS load [65]. 


\section{Conclusions}

In conclusion, in a specific concentration range, the potent ethylene action inhibitor $\left(\mathrm{AgNO}_{3}\right)$ enhances shoot regeneration from potato callus through an increase in polyamine content. At higher concentrations, polyamines are exhausted by the accompanying oxidative stress with subsequent inhibition of shoot regeneration.

Author Contributions: Conceptualization, E.-S.T.A.E.-S.; A.S.F.; M.E.E.-D., Y.S.A.M. and M.A.M.; methodology, W.M.R.M.A. and Y.S.A.M.; software, Y.S.A.M.; W.M.R.M.A.; validation, Y.S.A.M.; E.S.T.A.E.-S., A.S.F., M.E.E.-D. and M.A.M.; formal analysis, W.M.R.M.A.; investigation, W.M.R.M.A.; resources, M.E.E.-D. and M.A.M.; data curation, W.M.R.M.A.; writing-original draft preparation, Y.S.A.M. and W.M.R.M.A.; writing-review and editing E.-S.T.A.E.-S., A.S.F., Y.S.A.M., M.E.E.-D. and M.A.M.; visualization, Y.S.A.M. and W.M.R.M.A.; supervision, E.-S.T.A.E.-S., Y.S.A.M., A.S.F., M.E.E.-D. and M.A.M.; project administration, Y.S.A.M., M.E.E.-D. and M.A.M.; funding acquisition, M.E.E.-D., Y.S.A.M., M.A.M. and W.M.R.M.A. All authors have read and agreed to the published version of the manuscript.

Funding: The authors acknowledge the Deanship of Scientific Research at King Khalid University for funding this work through the Program of Research Groups under grant number (RGP 2/67/43).

Institutional Review Board Statement: Not applicable.

Informed Consent Statement: Not applicable.

Data Availability Statement: All data are represented in the text and figures.

Acknowledgments: The authors acknowledge the Deanship of Scientific Research at King Khalid University for funding this work through the Program of Research Groups under grant number (RGP 2/67/43). They also acknowledge Salah El-Din Ahmed Mohamedien, the director of the main vegetable crops and hybrid production project, the Egyptian Ministry of Agriculture and Land reclamation, for the facilities he provided for the completion of this work.

Conflicts of Interest: The authors declare no conflict of interest.

\section{References}

1. Devaux, A.; Goffart, J.-P.; Kromann, P.; Andrade-Piedra, J.; Polar, V.; Hareau, G. The Potato of the Future: Opportunities and Challenges in Sustainable Agri-Food Systems. Potato Res. 2021, 64, 681-720. [CrossRef] [PubMed]

2. Zaheer, K.; Akhtar, M.H. Potato Production, Usage, and Nutrition-a Review. Crit. Rev. Food Sci. Nutr. 2016, 56, 711-721. [CrossRef] [PubMed]

3. Zhang, H.; Fen, X.; Yu, W.; Hu, H.; Dai, X. Progress of Potato Staple Food Research and Industry Development in China. J. Integr. Agric. 2017, 16, 2924-2932. [CrossRef]

4. Maroufpour, B.; Rad, F.A.; Yazdanseta, S. Bioethanol Production as Biofuel from Potato Peel Using Saccharomyces Cerevisiae PTCC 5052 and Zymomonas Mobilis PTCC 1718. Bioagro 2019, 31, 177-184.

5. Diambra, L.A. Genome Sequence and Analysis of the Tuber Crop Potato. Nature 2011, 475, 189-195.

6. Hameed, A.; Zaidi, S.S.-A.; Shakir, S.; Mansoor, S. Applications of New Breeding Technologies for Potato Improvement. Front. Plant Sci. 2018, 9, 925. [CrossRef]

7. Fouad, A.; Hafez, R.; Hosni, H. Authentication of Three Endemic Species of the Caryophyllaceae from Sinai Peninsula Using DNA Barcoding. Egypt. J. Bot. 2019, 59, 483-491. [CrossRef]

8. Ashrafzadeh, S.; Leung, D.W. Novel Potato Plants with Enhanced Cadmium Resistance and Antioxidative Defence Generated after in Vitro Cell Line Selection. PLoS ONE 2017, 12, e0185621. [CrossRef]

9. Ricroch, A.E.; Hénard-Damave, M.-C. Next Biotech Plants: New Traits, Crops, Developers and Technologies for Addressing Global Challenges. Crit. Rev. Biotechnol. 2016, 36, 675-690. [CrossRef]

10. Ohnuma, M.; Teramura, H.; Shimada, H. A Simple Method to Establish an Efficient Medium Suitable for Potato Regeneration. Plant Biotechnol. J. 2020, 37, 25-30. [CrossRef]

11. Muktadir, M.A.; Habib, M.A.; Mian, M.A.K.; Akhond, M.A.Y. Regeneration Efficiency Based on Genotype, Culture Condition and Growth Regulators of Eggplant (Solanum melongena L.). Agric. Nat. Resour. 2016, 50, 38-42. [CrossRef]

12. Bordallo, P.N.; Silva, D.H.; Maria, J.; Cruz, C.D.; Fontes, E.P. Somaclonal Variation on in Vitro Callus Culture Potato Cultivars Hortic. Bras. 2004, 22, 300-304. [CrossRef]

13. Kumlay, A.M.; Ercisli, S. Callus Induction, Shoot Proliferation and Root Regeneration of Potato (Solanum tuberosum L.) Stem Node and Leaf Explants under Long-Day Conditions. Biotechnol. Biotechnol. Equip. 2015, 29, 1075-1084. [CrossRef]

14. Skoog, F.; Miller, C. Chemical Regulation of Growth and Organ Formation in Plant Tissues Cultured In Vitro. Symp. Soc. Exp. Biol. 1957, 11, 118-130. [PubMed] 
15. Hasanuzzaman, M.; Alhaithloul, H.A.S.; Parvin, K.; Bhuyan, M.; Tanveer, M.; Mohsin, S.M.; Nahar, K.; Soliman, M.H.; Mahmud, J.A.; Fujita, M. Polyamine Action under Metal/Metalloid Stress: Regulation of Biosynthesis, Metabolism, and Molecular Interactions. Int. J. Mol. Sci. 2019, 20, 3215. [CrossRef]

16. Rakesh, B.; Sudheer, W.; Nagella, P. Role of Polyamines in Plant Tissue Culture: An Overview. Plant Cell Tissue Organ. Cult. 2021, 145, 487-506. [CrossRef]

17. Evans, P.T.; Malmberg, R.L. Do Polyamines Have Roles in Plant Development? Annu. Rev. Plant Biol. 1989, 40, 235-269. [CrossRef]

18. Bais, H.P.; Ravishankar, G. Role of Polyamines in the Ontogeny of Plants and Their Biotechnological Applications. Plant Cell Tissue Organ. Cult. 2002, 69, 1-34. [CrossRef]

19. Apelbaum, A.; Goldlust, A.; Icekson, I. Control by Ethylene of Arginine Decarboxylase Activity in Pea Seedlings and Its Implication for Hormonal Regulation of Plant Growth. Plant Physiol. 1985, 79, 635-640. [CrossRef]

20. Smith, T. Plant Polyamines Metabolism And Function Polyamine Synthesis. In Polyamines And Ethylene: Biochemistry, Physiology And Interaction; American Society of Plant Physiologists: Rockville, MD, USA, 1985; pp. 1-23.

21. Zhao, X.-C.; Qu, X.; Mathews, D.E.; Schaller, G.E. Effect of Ethylene Pathway Mutations upon Expression of the Ethylene Receptor ETR1 from Arabidopsis. Plant Physiol. 2002, 130, 1983-1991. [CrossRef]

22. Kumar, V.; Parvatam, G.; Ravishankar, G.A. AgNO 3 : A Potential Regulator of Ethylene Activity and Plant Growth Modulator. Electron. J. Biotechnol. 2009, 12, 8-9. [CrossRef]

23. Salem, J. Effects of Anti-Ethylene Compounds on Vitrification and Genome Fidelity of Stevia rebaudiana Bertoni. Egypt. J. Bot. 2020, 60, 519-535. [CrossRef]

24. Strader, L.C.; Beisner, E.R.; Bartel, B. Silver Ions Increase Auxin Efflux Independently of Effects on Ethylene Response. Plant Cell 2009, 21, 3585-3590. [CrossRef] [PubMed]

25. Kaur, A.; Reddy, M.S.; Kumar, A. Efficient, One Step and Cultivar Independent Shoot Organogenesis of Potato. Physiol. Mol. Biol. Plants 2017, 23, 461-469. [CrossRef]

26. Alva Ticona, S.; Oropeza, M. Effect of Culture Medium Consistence and Silver Nitrate on Micropropagation of Two Potato (Solanum tuberosum) Cultivars. Rev. Colomb. Biotecnol. 2013, 15, 55-62. [CrossRef]

27. Murashige, T.; Skoog, F. A Revised Medium for Rapid Growth and Bio Assays with Tobacco Tissue Cultures. Physiol. Plant 1962, 15, 473-497. [CrossRef]

28. Merwad, A.-R.M.; Desoky, E.-S.M.; Rady, M.M. Response of Water Deficit-Stressed Vigna unguiculata Performances to Silicon, Proline or Methionine Foliar Application. Sci. Hortic. 2018, 228, 132-144. [CrossRef]

29. Sestak, Z.; Catsky, J.; Jarvis, P. Determination of Chlorophylls a and b. Plant Photosynth. Prod. 1971, 672-701.

30. Minocha, R.; Shortle, W.C.; Long, S.L.; Minocha, S.C. A Rapid and Reliable Procedure for Extraction of Cellular Polyamines and Inorganic Ions from Plant Tissues. J. Plant Growth Regul. 1994, 13, 187-193. [CrossRef]

31. Federico, R.; Angelini, R.; Cogoni, A.; Floris, V. Enzymatic Methods for the Quantification of Polyamines Using Plant Amine Oxidases. Biochem. Physiol. Pflanz. 1991, 187, 113-119. [CrossRef]

32. Loreto, F.; Velikova, V. Isoprene Produced by Leaves Protects the Photosynthetic Apparatus against Ozone Damage, Quenches Ozone Products, and Reduces Lipid Peroxidation of Cellular Membranes. Plant Physiol. 2001, 127, 1781-1787. [CrossRef] [PubMed]

33. Stewart, R.R.; Bewley, J.D. Lipid Peroxidation Associated with Accelerated Aging of Soybean Axes. Plant Physiol. 1980, 65, 245-248. [CrossRef] [PubMed]

34. Tice, R.R.; Agurell, E.; Anderson, D.; Burlinson, B.; Hartmann, A.; Kobayashi, H.; Miyamae, Y.; Rojas, E.; Ryu, J.-C.; Sasaki, Y. Single Cell Gel/Comet Assay: Guidelines for in Vitro and in Vivo Genetic Toxicology Testing. Environ. Mol. Mutagen. 2000, 35, 206-221. [CrossRef]

35. Ghosh, S.; Majumdar, S.; Sarkar, D.; Datta, K. An Efficient Adventitious Shoot Regeneration System for Potato (Solanum tuberosum L.) Using Leaf Discs. J. Plant Biochem. Biotechnol. 2015, 24, 298-304. [CrossRef]

36. Xu, C.; Cao, H.; Zhang, Q.; Wang, H.; Xin, W.; Xu, E.; Zhang, S.; Yu, R.; Yu, D.; Hu, Y. Control of Auxin-Induced Callus Formation by BZIP59-LBD Complex in Arabidopsis Regeneration. Nat. Plants 2018, 4, 108-115. [CrossRef]

37. Shin, J.; Seo, P.J. Varying Auxin Levels Induce Distinct Pluripotent States in Callus Cells. Front. Plant Sci. 2018, 9, 1653. [CrossRef]

38. Bidabadi, S.S.; Jain, S.M. Cellular, Molecular, and Physiological Aspects of in Vitro Plant Regeneration. Plants 2020, 9, 702. [CrossRef]

39. Kaur, A.; Kumar, A. The Effect of Gelling Agent, Medium PH and Silver Nitrate on Adventitious Shoot Regeneration in Solanum Tuberosum. bioRxiv 2020. [CrossRef]

40. Shah, S.H.; Ali, S.; Jan, S.A.; Din, J.; Ali, G.M. Assessment of Silver Nitrate on Callus Induction and in Vitro Shoot Regeneration in Tomato (Solanum lycopersicum Mill.). Pak. J. Bot. 2014, 46, 2163-2172.

41. Hayta, S.; Smedley, M.A.; Li, J.; Harwood, W.A.; Gilmartin, P.M. Plant Regeneration from Leaf-Derived Callus Cultures of Primrose (Primula vulgaris). HortScience 2016, 51, 558-562. [CrossRef]

42. Warchol, M.; Juzoń, K.; Dziurka, K.; Czyczylo-Mysza, I.; Kaploniak, K.; Marcińska, I.; Skrzypek, E. The Effect of Zinc, Copper, and Silver Ions on Oat (Avena sativa L.) Androgenesis. Plants 2021, 10, 248. [CrossRef] [PubMed]

43. Malik, W.A.; Mahmood, I.; Razzaq, A.; Afzal, M.; Shah, G.A.; Iqbal, A.; Zain, M.; Ditta, A.; Asad, S.A.; Ahmad, I.; et al. Exploring Potential of Copper and Silver Nano Particles to Establish Efficient Callogenesis and Regeneration System for Wheat (Triticum aestivum L.). GM Crops Food 2021, 12, 564-585. [CrossRef] [PubMed] 
44. Giridhar, P.; Indu, E.; Vijaya Ramu, D.; Ravishankar, G. Effect of Silver Nitrate on in Vitro Shoot Growth of Coffee. Trop. Sci. 2003, 43, 144-146. [CrossRef]

45. Kaur, A.; Reddy, M.S.; Kumar, A. Direct Somatic Embryogenesis of Potato [Solanum tuberosum (L.)] Cultivar 'Kufri Chipsona 2'. Plant Cell Tissue Organ. Cult. 2018, 134, 457-466. [CrossRef]

46. Turhan, H. The Effect of Silver Nitrate (Ethylene Inhibitor) on in Vitro Shoot Development in Potato (Solanum tuberosum L.). Biotechnology 2004, 3, 72-74.

47. Vaseva, I.I.; Qudeimat, E.; Potuschak, T.; Du, Y.; Genschik, P.; Vandenbussche, F.; Van Der Straeten, D. The Plant Hormone Ethylene Restricts Arabidopsis Growth via the Epidermis. Proc. Natl. Acad. Sci. USA 2018, 115, E4130-E4139. [CrossRef]

48. Feray, A.; Hourmant, A.; Brun, A.; Penot, M. Effect of Polyamines on Morphogenesis of in Vitro Potato Plants (Solanum tuberosum Cv. Bintje). C. R. Acad. Sci. Sér. 3 Sci. Vie 1993, 316, 1446-1451.

49. Vondráková, Z.; Eliášová, K.; Vágner, M.; Martincová, O.; Cvikrová, M. Exogenous Putrescine Affects Endogenous Polyamine Levels and the Development of Picea abies Somatic Embryos. Plant Growth Regul. 2015, 75, 405-414. [CrossRef]

50. Aragão, V.P.M.; Reis, R.S.; Silveira, V.; Santa-Catarina, C. Putrescine Promotes Changes in the Endogenous Polyamine Levels and Proteomic Profiles to Regulate Organogenesis in Cedrela fissilis Vellozo (Meliaceae). Plant Cell Tissue Organ. Cult. 2017, 130, 495-505. [CrossRef]

51. Ahlawat, J.; Sehrawat, A.R.; Choudhary, R.; Samarina, L.; Bandaralage, J.-H.; Chaudhary, R. Quantifying Synergy of Plant Growth Hormones, Anti-Oxidants, Polyamines and Silver Nitrate for Optimizing the Micro Propagation of Capparis decidua: An Underutilised Medicinal Shrub. Nucleus 2020, 63, 313-325. [CrossRef]

52. Khoshbakht, D.; Asghari, M.; Haghighi, M. Influence of Foliar Application of Polyamines on Growth, Gas-Exchange Characteristics, and Chlorophyll Fluorescence in Bakraii citrus under Saline Conditions. Photosynthetica 2018, 56, 731-742. [CrossRef]

53. Yousefi, F.; Jabbarzadeh, Z.; Amiri, J.; Rasouli-Sadaghiani, M.H. Response of Roses (Rosa hybrida L.'Herbert Stevens') to Foliar Application of Polyamines on Root Development, Flowering, Photosynthetic Pigments, Antioxidant Enzymes Activity and NPK. Sci. Rep. 2019, 9, 1-11.

54. Kim, J.K.; Baskar, T.B.; Park, S.U. Silver Nitrate and Putrescine Enhance In vitro Shoot Organogenesis in Polygonum tinctorium. Biosci. Biotechnol. Res. Asia 2016, 13, 53-58. [CrossRef]

55. Tripathi, A.; Liu, S.; Singh, P.K.; Kumar, N.; Pandey, A.C.; Tripathi, D.K.; Chauhan, D.K.; Sahi, S. Differential Phytotoxic Responses of Silver Nitrate (AgNO3) and Silver Nanoparticle (AgNps) in Cucumis sativus L. Plant Gene 2017, 11, 255-264. [CrossRef]

56. Noori, A.; Donnelly, T.; Colbert, J.; Cai, W.; Newman, L.A.; White, J.C. Exposure of Tomato (Lycopersicon esculentum) to Silver Nanoparticles and Silver Nitrate: Physiological and Molecular Response. Int. J. Phytoremediation 2020, 22, 40-51. [CrossRef] [PubMed]

57. De Veylder, L.; Beeckman, T.; Inzé, D. The Ins and Outs of the Plant Cell Cycle. Nat. Rev. Mol. Cell Biol. 2007, 8, 655-665. [CrossRef] [PubMed]

58. Hafez, R.; Fouad, A. Mitigation of Genotoxic and Cytotoxic Effects of Silver Nanoparticles on Onion Root Tips Using Some Antioxidant Scavengers. Egypt. J. Bot. 2020, 60, 133-145. [CrossRef]

59. Chen, X.-B.; Zhao, X.-H.; Zhu, Y.; Gong, Y.-D.; Li, L.-B.; Zhang, J.-P.; Kuang, T.-Y. Hydrogen Peroxide-Induced Chlorophyll a Bleaching in the Cytochrome b $6 \mathrm{f}$ Complex: A Simple and Effective Assay for Stability of the Complex in Detergent Solutions. Photosynth. Res. 2006, 90, 205-214. [CrossRef]

60. Dai, H.; Shan, C. Others Effects of Lanthanum on the Antioxidant Capacity of Chloroplasts and Chlorophyll Fluorescence Parameters of Maize Seedlings under Chromium Stress. Photosynthetica 2019, 57, 27-31. [CrossRef]

61. Santos, C.L.; Pourrut, B.; Oliveira, J.M.P. The Use of Comet Assay in Plant Toxicology: Recent Advances. Front. Genet. 2015, 6, 216 [CrossRef]

62. Szpunar-Krok, E.; Jańczak-Pieniążek, M.; Skrobacz, K.; Bobrecka-Jamro, D.; Balawejder, M. Response of Potato (Solanum tuberosum L.) Plants to Spraying by Hydrogen Peroxide. Sustainability 2020, 12, 2469. [CrossRef]

63. Dikilitas, M.; Collins, A.R.; Kocyigit, A.; El Yamani, N.; Karakas, S. DNA Damage in Potato Plants Exposed to High Level of NaCl Stress. In Proceedings of the Frontiers in Genetics, Conference Abstract: ICAW, Antwerpen, Belgium, 1-4 September 2015.

64. Vishwakarma, K.; Upadhyay, N.; Singh, J.; Liu, S.; Singh, V.P.; Prasad, S.M.; Chauhan, D.K.; Tripathi, D.K.; Sharma, S. Differential Phytotoxic Impact of Plant Mediated Silver Nanoparticles (AgNPs) and Silver Nitrate ( $\left.\mathrm{AgNO}_{3}\right)$ on Brassica Sp. Front. Plant Sci. 2017, 8, 1501. [CrossRef] [PubMed]

65. Seo, S.Y.; Kim, Y.J.; Park, K.Y. Increasing Polyamine Contents Enhances the Stress Tolerance via Reinforcement of Antioxidative Properties. Front. Plant Sci. 2019, 10, 1331. [CrossRef] [PubMed] 